\title{
A justiça penal internacional e a África: a "africanização" do direito internacional penal
}

\author{
International criminal justice and Africa: from "Afrocentrism" to "Africanization" of \\ International Criminal Law
}

Juliette Marie Marguerite Robichez

\section{Resumo}

As vicissitudes da justiça penal internacional (JPI) e, em particular, o pretendido "afrocentrismo" do Tribunal Penal Internacional (TPI), que concentraria suas atividades exclusivamente contra os ditadores africanos, são denunciadas de maneira recorrente. Se a jurisdição criminal de cunho universal, criada em 1998, não constitui a panaceia para condenar todos os dirigentes que cometem crimes internacionais, não podemos negar, todavia, o impacto positivo que ela já induziu: a sua finalidade não é julgar todos os carrascos do planeta, mas oferecer um paradigma de justiça imparcial e respeitosa das garantias processuais fundamentais e, dessa forma, estimular as jurisdições nacionais a endossar suas responsabilidades ao processar seus responsáveis por crimes de lesa-humanidade cometidos no seu território. Nesse sentido, o fato de os Estados africanos imaginarem alternativas regionais ao TPI pode ser considerado como uma contribuição positiva da JPI à luta contra a impunidade. Com a finalidade de estudar o novo fenômeno de "africanização" (no sentido definido por Achille Mbembe, de uma África percebida como laboratório vivo onde se delineiam as figuras do mundo vindouro) do direito internacional penal, realizou-se uma pesquisa bibliográfica, com enfoque na literatura africana, baseada em procedimentos metodológicos comparativos e históricos, guiada por uma abordagem dedutiva amparada, notadamente no estudo de tratados e de casos jurisprudenciais internacionais. A pesquisa utiliza o escopo da teoria da interdependência complexa, defendida por R. Keohane e J. Nye, que ressalta a relevância dos atores transnacionais para estudar e compreender as relações internacionais. O primeiro tópico será consagrado às contribuições e aporias dos tribunais criminais internacionais ad hoc, em particular o Tribunal Penal Internacional para Ruanda e o Tribunal penal para a Ex-lugoslávia e ao TPI de cunho permanente, que provocaram o movimento de africanização da JPI. O segundo examinará uma das primeiras manifestações dessa regionalização do DPI, a saber, a criação das jurisdições criminais híbridas, como o Tribunal Especial para a Serra Leoa e as Câmaras Africanas Extraordinárias. O terceiro tópico abordará a relevância da tentativa de implantação de um tribunal penal internacional africano de caráter permanente, iniciativa que visa adaptar a JPI às particularidades e aos anseios do continente negro.

Palavras-chave: Africanização. Câmaras Africanas Extraordinárias. Regionalização. Tribunal Penal Internacional africano. Tribunais Penais Internacionais. Tribunal Especial para a Serra Leoa.

\section{Abstract}

The vicissitudes of international criminal justice (ICJ) and, in particular, the so-called "Afrocentrism" of the International Criminal Court (ICC), which would focus exclusively its activities against African dictators, are recurrently reported. If this universal criminal jurisdiction, created in 1998, does not constitute the panacea for condemning all leaders who commit international crimes, we cannot deny the positive impact it has already induced: its purpose is not to judge all the executioners of the planet, but to offer an impartial and justice paradigm that respects fundamental procedural guarantees, and this way, encourage national jurisdictions to endorse their responsibilities in prosecuting those responsible for crimes against humanity committed on their territory. In this sense, the fact that African states envisage regional alternatives to the ICC can be considered as a positive contribution of the ICJ to the struggle against impunity. In order to study the new phenomenon of "africanization" (in the sense, defined by Achille Mbembe, of an Africa perceived as a living laboratory in which figures of the world to come are outlined) of international criminal law, a qualitative and bibliographical research has been carried out, focusing on African literature, based on comparative and historical methodological approach, guided by a deductive approach supported, notably, in treaties and case law studies. The research uses the scope of complex interdependence theory, defended por R. Keohane e J. Nye, that highlights the relevance of transnational actors to study and understand international relations. The first chapter will be devoted to the contributions and difficulties of the ad hoc international criminal

* D Doutora e Mestre em Direito pela Universidade Paris I - Panthéon Sorbonne (França). Professora de Direito Internacional e Direitos Humanos nos cursos de Direito e Relações Internacionais na Bahia e no Brasil. Presidente da Comissão de Direito Internacional do Instituto dos Advogados da Bahia (CDI-IAB). Salvador - BA - Brasil. E-mail: julietterobichez@yahoo.fr. 
tribunals, particularly the International Criminal Court for the Former Yugoslavia and the International Criminal Tribunal for Rwanda, and the permanent ICC, that triggered the ICJ Africanization movement. The second one will examine one of the main manifestations of this regionalization of ICJ, namely the creation of hybrid criminal jurisdictions, such as the Special Court for Sierra Leone and the Extraordinary African chambers and the Special Court for Sierra Leone. The third chapter will deal with the relevance of the attempt to establish a permanent African International Criminal Court, an initiative that aims to adapt ICJ to the particularities and aspirations of the black continent.

Keywords: Africanization. Extraordinary African Chambers. Regionalization. African International Criminal Court. International Criminal Tribunals. Special Court for Sierra Leone.

\section{Introdução}

A justiça penal internacional (JPI) de caráter universal, encarnada pelo Tribunal Penal Internacional (TPI), sem dúvida é um dos grandes marcos do sistema internacional de proteção dos direitos humanos, que suscitou grandes esperanças. O juiz internacional Antônio Augusto Trindade $(2015$, p. 26) considera que "o legado mais precioso do pensamento jurisinternacionalista da segunda metade do século XX reside na consolidação da personalidade e capacidade jurídicas internacionais da pessoa humana" e que "as jurisdições internacionais contribuíram a assegurar a centralidade das vítimas no processo legal internacional". Todavia ela não constitui ainda a panaceia para lutar contra a impunidade das pessoas que cometeram um crime internacional, pelo menos do ponto de vista dos africanos (ROBICHEZ, 2018). As vicissitudes da jurisdição criminal internacional de caráter permanente, criada pelo Estatuto de Roma em 1998, são conhecidas e denunciadas. Além de ser apresentada como hegemônica, a justiça dita universal é marcada pela história do direito penal ocidental, caracterizado por seu individualismo e moralismo (BERNARD, 2014, p. 63; NGAMENI, 2017). Segundo os dados consultados no site do TPI, entre julho de 2002 - data da entrada em vigor do seu ato constitutivo - e agosto de 2019, a Corte sediada em Haia foi acionada em 27 casos. Os 45 acusados de crimes de genocídio, crimes contra a humanidade e/ou de crimes de guerra, exceto um, são oriundos do continente africano, ${ }^{1}$ e $100 \%$ dos condenados são igualmente africanos, fato que a doutrina resume com o neologismo pejorativo de "afrocentrismo" (HABA, 2013). ${ }^{2}$ Difícil, nessas condições, denegar a denominação irônica de "Tribunal da África" (BENVENUTO, 2016) usada pela União Africana (UA), maior organização internacional do continente, que se sente traída (AFRICAN UNION, 2017). Dirigentes expressaram suas dúvidas no tocante à imparcialidade do TPI ao qualificá-lo de órgão "racista e neocolonial", que exerceria uma "justiça seletiva". Mesmo que se possa refutar as críticas endereçadas ao TPI (ROBICHEZ, 2018), os números citados acima são eloquentes.

No entanto podemos propor outra leitura desse pretendido afrocentrismo do TPI. Como um dos primeiros juízes dos tribunais penais internacionais concluiu em um documentário, relatando a gênese da justiça penal internacional (LE COMBAT DES JUGES, 2000), a finalidade da criação de uma jurisdição criminal de cunho universal não é julgar todos os carrascos do planeta, mas oferecer um paradigma de justiça imparcial e respeitosa das garantias processuais fundamentais e, dessa forma, estimular as jurisdições nacionais a endossar suas responsabilidades ao processar seus responsáveis de crimes de lesa-humanidade cometidos no seu território.

Nesse sentido, o fato de os Estados africanos imaginarem uma alternativa regional ao TPI, ao criar tribunais híbridos, pode ser considerado como uma contribuição positiva da justiça penal internacional à luta contra a impunidade. Recentemente, assistimos ao surgimento de uma "africanização" do direito internacional penal, a qual desperta nossa curiosidade. Esse fenômeno ilustra perfeitamente o que uma das maiores figuras intelectuais atuais defende: a futura e desejada "africanização do mundo". Achille Mbembe, grande leitor de Frantz Fanon, na sua obra toda, como em Crítica da razão negra do mundo (2014), publicada na França em 2013, reconhece que se a África constituiu e continua a constituir o local onde prospera uma globalização desenfreada e sem piedade, ela é também predestinada por se tornar um laboratório de uma nova humanidade, aberta à pluralidade dos mundos, o epicentro de transformações rápidas e de uma amplitude inédita. Na temática que interessa a este artigo, uma das ideias que surgiu logo no início do milênio, para sair do impasse no qual se encontra o berço da humanidade,

\footnotetext{
São oriundos da República Democrática do Congo, da Uganda, do Sudão (Darfur), da República Centro Africana, do Kenya, do Costa do Marfim, do Mali e do Burundi. O único Estado não africano é a Geórgia.

2 Insta salientar que não se trata, neste artigo, do conceito afrocentrismo criado verossimilmente pelo pan-africanista W.E.B. Du Bois e o historiador Cheikh Anta Diop, desenvolvido atualmente por Molefi Kete Asante. O Afrocentrism é uma ideologia dedicada ao estudo da história africana, cuja finalidade é valorizar a cultura e a história dos afro-americanos e lutar contra o racismo global (EARLY, s. d).
} 
é confiar o papel de julgar os autores de crimes internacionais ao continente. "Cabe aos africanos julgar seus monstros", reivindica outro escritor dos Camerões, Yann Gwet (2016).

Como sugere o pesquisador da Universidade de Ouagadougou, Abdoulaye Soma, precisamos repensar a dialética do universalismo e do regionalismo na repressão penal internacional. Doravante o Direito Internacional Penal (DPI) - sub-ramo do Direito Internacional Público que abrange o conjunto de regras e instituições que governam a incriminação e a repressão das infrações definidas pela ordem jurídica internacional - requer ser conjugado com o desenvolvimento progressivo de um direito penal no plano continental. $O$ direito criminal internacional, que surgiu nos anos 90, na sua formação, sua evolução e sua aplicação, se inscreveu globalmente em uma dinâmica universalista (ASCENSIO et alii, 2012, p. 16) ou, dito de outro modo, foram adotadas regras e instituições uniformes e comuns destinadas a regular a sociedade internacional como conjunto. A implantação das jurisdições penais internacionais, do Tribunal Penal Internacional para a ex-lugoslávia (TPII), do Tribunal Penal Internacional para Ruanda (TPIR) e do TPI ou dos tribunais híbridos, como o Tribunal Especial para a Serra Leoa (SCSL segundo o acrônimo em inglês), foi feita nos auspícios da organização universal que é a ONU.

No entanto leciona Jorge Miranda (2012, p. 23 e s.) que, se a "universalização" é a primeira tendência do desencadear da evolução do Direito Internacional Público, a "regionalização" constitui logicamente a segunda. O regionalismo pode ser concebido como um fenômeno de desenvolvimento de normas e organizações internacionais próprias a uma parte da comunidade internacional. Já em 1932 era considerado por George Scelle (1993, p. 271; adde SOMA, 2015, p. 7) como uma "evolução natural" do direito das gentes. Com efeito, todo o direito internacional geral é irrigado e irradiado pelo movimento de regionalização. ${ }^{3}$ Hodiernamente, o organismo universal "terceiriza", segundo as palavras de doutrinadores franceses (BRICHAMBAUT et alii, 2011, p. 445), sua função de manutenção da paz e da segurança internacionais, ao autorizar intervenções militares e operações de missão de paz regionais. ${ }^{4}$ A hipótese, aliás, foi vislumbrada pelo ex-secretário geral das NU, Boutros Boutros Ghali, em 1992, na Agenda para a Paz:

Conforme a Carta, o Conselho de Segurança tem - e continuará a ter - a responsabilidade principal de manutenção da paz e da segurança internacionais, mas a ação regional, via a regionalização, a delegação e a cooperação dos esforços da ONU, poderia não somente tornar mais leve a tarefa do Conselho mas contribuir igualmente para a criação de um sentimento mais forte de participação, de consenso e de democratização, no que tange os casos internacionais. (BOUTROS GHALI, 1992, § 64, p. 20. Tradução livre; grifo nosso).

Parece que é justamente esse sentimento mais forte de participação, de consenso e de democratização que mobiliza os africanos, tanto seus governantes quanto seus intelectuais, para pensar e oferecer soluções locais mais respeitosas das suas soberanias e mais atentas às suas expectativas e particularidades. Esse regionalismo pode ser visto como comportando um risco de fragmentação e enfraquecimento do direito internacional geral ou, ao contrário, como a expressão do pluralismo, do particularismo e do relativismo imanentes à sociedade internacional. Desde a descolonização, o continente africano, que abriga Estados considerados da periferia, tem inclinação para um direito descentralizado, não mais dominado pelo eurocentrismo e refletindo a heterogeneidade das sociedades nacionais que ele regula.

Assim, o regionalismo não poupou o direito penal internacional. Segundo o professor Soma, citado acima, como a África cristaliza a implementação da justiça penal internacional (primeira decisão do TPI concerniu a um africano, o primeiro chefe de Estado inculpado é um africano...), o continente negro é legitimamente impelido a refletir sobre a oportunidade de desenvolver seu próprio dispositivo penal regional e, assim, tornar efetivo o princípio de subsidiariedade que prevê a primazia da competência das jurisdições nacionais sobre a internacional (artigos 1 e 17 do Estatuto de Roma, de 1998). Esse continente já encetou o fenômeno da "africanização" do direito internacional penal, e pretendemos demonstrar que o processo é irreversível e já demonstrou sua eficácia.

3 Podemos pensar nos direitos humanos que, depois da adoção da Declaração Universal dos Direitos Humanos de 1948, conheceram um destino notável nos sistemas europeus, americanos e africanos. Da mesma forma, a Carta da ONU, indiretamente, reconheceu um papel importante às organizações regionais no quadro da segurança coletiva. Da mesma forma, foram os países latino-americanos, constituindo a metade dos Estados presentes na Conferência de São Francisco, todos apegados à preservação das instituições interamericanas existentes, que reivindicaram e influenciaram a redação dos artigos do capítulo VIII do ato constitutivo da ONU, intitulado "Acordos regionais" que permitiu a regionalização das operações de missão de paz.

4 Ver exemplos de cooperação, em particular no continente africano, entre as operações de manutenção de paz da ONU e as da OUA, antecessora da UA ou da CEDEAO. 
Com essa finalidade, realizou-se uma pesquisa qualitativa, bibliográfica e documental, com enfoque na literatura africana, baseada em procedimentos metodológicos comparativos e históricos, guiada por uma abordagem dedutiva amparada, notadamente, no estudo de casos jurisprudenciais. A pesquisa proposta por este estudo utiliza o escopo da teoria neoliberalista, em sua vertente aplicada às relações internacionais. Autores como Robert Keohane e Joseph Nye $(1971,1989,2001)$ foram os primeiros a ressaltar a relevância dos atores transnacionais para estudar e compreender as relações internacionais. Essa abordagem, chamada de interdependência complexa, considera que, no mundo moderno, as relações internacionais não podem mais ser reduzidas pelo caos e pelo estado de guerra, como o resumiam defensores das teorias realistas inspirados pela obra de Thomas Hobbes, mas, ao contrário, deveria tomar em consideração seu grau de ordenamento, caracterizado pelas instituições internacionais. Não temos dúvida que as organizações regionais, as jurisdições criminais em particular, participam do movimento de descentralização e de institucionalização que afeta o comportamento dos Estados.

O primeiro tópico será consagrado aos tribunais penais internacionais pioneiros, que, de maneira paradoxal, serviram de laboratório à criação de uma justiça penal internacional universal, inicialmente desejada, e são hoje objeto de repulsão. Suas aporias provocaram o surgimento do novo fenômeno que eclodiu no continente africano; a saber, a regionalização da justiça penal, objeto do nosso estudo. Esse movimento de africanização da JPI segue duas direções: a primeira é a criação da nova figura dos tribunais híbridos, que será estudada no segundo tópico; a outra direção consiste na implantação de uma jurisdição permanente africana, ainda hoje uma tentativa, que será examinada no terceiro tópico. Para cada uma dessas recentes iniciativas, será ressaltado o particularismo do regionalismo africano no intuito de questionar a legitimidade do fenômeno e sua operacionalidade.

\section{Contribuições e aporias da justiça penal internacional de caráter universal}

Nesta seção, não pretendemos esgotar a questão das contribuições e aporias da justiça penal de cunho universal, tema amplamente estudado na literatura, mas entender a lógica do desencadeamento dos fatos que levaram os Estados africanos a reagir e imaginar soluções regionais mais adequadas às suas realidades. Por marcar o início da difusão do DIP no continente africano, ${ }^{5}$ destacaremos a experiência do Tribunal Penal Internacional para Ruanda (TPIR).

Como em 1992, no conflito da ex-lugoslávia, a solução alternativa procurada pela sociedade internacional para amenizar o fracasso da missão de paz da ONU em impedir o genocídio mais rápido da história ${ }^{6}$ foi a implementação de uma jurisdição penal internacional encarregada de julgar os hutus que massacraram os tutsis e os hutus moderados do pequeno país conhecido como a "Terra das mil colinas". Em 1994, a Resolução n. ${ }^{\circ} 955$ do CS/NU criou o TPIR, sediado em Arusha, na Tanzânia. Aproveitando a experiência do tribunal ad hoc antecessor, o Tribunal Penal para a Ex-lugoslávia (TPII), o Tribunal de Arusha consolidou e aperfeiçoou as normas de funcionamento e os códigos penal e de processo penal internacionais. Julgou os principais representantes do Estado que planejaram o massacre de uma parte da sua população por razões étnicas. O último veredito foi pronunciado, no dia 14 de dezembro de 2015, contra a ex-ministra da Família e da Promoção Feminina. Pauline Nyiramsuhuko, primeira mulher indiciada por genocídio por um tribunal internacional, foi condenada, em apelo, a uma pena de 47 anos de prisão. Das 93 pessoas acusadas, 61 foram condenadas, algumas à prisão perpétua, como o ex-premiê Jean Kambada, em primeira instância, e 14 foram absolvidas. O mecanismo para os tribunais penais internacionais da ONU, com as jurisdições nacionais que gozam da competência nacional e os gacacas, jurisdições populares ruandesas, assume doravante a continuação das atividades do Tribunal de Arusha.

Apesar desse balanço, o Tribunal sofreu muitas críticas (OLIVIER, 2015; LEPIDI, 2015; PETITE, 2015), ilações preciosas para a elaboração do futuro tribunal permanente. A justiça praticada por ele foi considerada lenta, onerosa (em comparação com o pequeno número de suspeitos julgados) e pouco empática com as vítimas, que intervieram no processo somente em qualidade de testemunhas e que não obtiveram reparação. ${ }^{7}$ Porém a crítica

5 Danilo Zolo, no seu livro La justice des vainqueurs (2009, p. 48), lembra que existe uma tentativa anterior às atrocidades de 1994 em Ruanda de difusão das normas internacionais penais no continente negro. Em 1949, o Estado etíope fez um pedido de extradição à Itália dos generais Pietro Badoglio e Rodolfo Graziani para que eles sejam julgados por um tribunal internacional, composto de magistrados de várias nacionalidades, por ter perpetrados crimes de guerra.

6 800.000/1milhão de mortos, 250.000 estupros em 3 meses. Assistir aos filmes de Raoul PECK, Sometimes in april (2005), de Roger SPOTTISWOODE, Shake hands with the devil (2007) e Terry GEORGE, Hotel Ruanda (2004).

7 De modo geral, os tribunais penais internacionais ad hoc, que não possuem uma polícia própria, carecem de operacionalidade, pois dependem da boa vontade de cooperação dos Estados para entregar os foragidos, por exemplo. Porém, no tocante ao TPIR, a colaboração dos Estados africanos e europeus permitiu julgar todos que foram acusados. 
principal está ligada ao seu caráter político, que é corroborado pelo fato de os procuradores serem designados pelos cinco membros permanentes do CS/NU. Assim, o TPIR foi estigmatizado por não ser imparcial: não foram contemplados os eventuais crimes cometidos pela Fronte Patriótica Ruandesa (FPR), partido do atual presidente, Paul Kagamé, que perpetrou crimes internacionais ao intervir para parar o genocídio. Da mesma forma, não foram examinadas as responsabilidades de indivíduos implicados nos genocídios oriundos das potências estrangeiras envolvidas, como a França.

Apesar dessas ponderações sobre a atuação dos tribunais ad hoc, o TPIR, como o TPII, serviram de laboratório para urdir uma jurisdição penal com âmbito universal e com caráter permanente, que respondia às aspirações dos que lutam em prol dos direitos humanos. O Tribunal Penal Internacional (TPI) não escapará, todavia, de todas as críticas às jurisdições antecessoras endereçadas, em particular de ser um tribunal parcial por ser político (ROBICHEZ, 2018). O pretendido afrocentrismo dessa jurisdição provocou a reação dos países africanos, que, para afirmar sua soberania nacional e dominar seu destino, optaram por uma solução regional para julgar seus "monstros". Segundo um professor suíço, especialista em justiça transicional, "o principal mérito do TPI é estimular os países a agir por eles mesmos e de ficar uma corte de última instância. E olhem: não contamos mais as iniciativas de mediação locais, as comissões verdade e reconciliação no modelo sul-africano" (LEPIDI, 2015. Tradução livre). Yann Gwet (2016), logo depois do XXVI Cúpula da UA em Adis-Abeba, onde a instituição regional ameaçou a denúncia coletiva dos Estados africanos ao Estatuto de Roma de 1998, inspira-se na poeta Jordan June para proclamar a necessidade de acabar com o neocolonialismo e inventar novas soluções regionais:

Melhor ter uma soberania infeliz que uma servidão feliz... para nós que acreditamos que o progresso é indissociável de uma total autonomia política, o apoio ao projeto da UA de sair do TPI não é um apoio aos tiranos continentais. É simplesmente a afirmação que estamos bem os que esperamos (tradução livre).

Os desafios do continente africano são grandes: em primeiro lugar, conciliar o princípio de soberania com o princípio de respeito aos direitos humanos (lutar contra a impunidade) e, em segundo lugar, aliar a exigência de justiça e a necessidade de reconciliar as sociedades que conheceram crimes em massa. A resposta é de ordem política, judiciária, mas também de ordem íntima, pois cada um tem sua concepção da justiça e da dignidade. Os africanos têm consciência da necessidade de agregar a ordem jurídica moderna, imposta pelas potências ocidentais durante a colonização, e a ordem jurídica tradicional, que conseguiu resistir apesar das políticas de "aculturação" imposta pelos colonizadores, que prega uma filosofia jurídica diferente da do direito internacional penal. $\mathrm{O}$ direito criminal tradicional africano se refere à ordem jurídica repressiva enraizada nas sociedades; considerado, às vezes, arcaico, mas que sobrevive no campo onde mora a maioria dos habitantes. É constituído de normas consuetudinárias e religiosas. Ora, segundo Herman Blaise Ngameni (2017, p. 38), a essência da justiça costumeira africana reside no desejo de conciliação e de manutenção da paz social. A experiência das gacaca, os tribunais comunitários ruandeses que julgaram os que participaram do genocídio de 1994, é testemunha dessa preocupação em aliar os interesses do indivíduo com os do grupo ao qual ele pertence (por ex. CLARK, 2010). O princípio de complementaridade da JPI convida a articular melhor o direito internacional com os direitos nacionais.

Nesse diapasão, os africanos não careceram de imaginação para favorecer um diálogo entre os juízes nacionais e internacionais e criar soluções alternativas, como os tribunais híbridos que serviram de modelo em outras partes do mundo.

\section{Os tribunais híbridos do continente africano}

Como prega a teoria da interdependência (KEOHANE; NYE, 2011), o impacto das jurisdições criminais regionais na política penal dos Estados varia de acordo com dois fatores: a) manifestação pelos Estados de interesses mútuos em cooperar para lutar contra o que eles consideram o imperialismo do TPI; b) necessidade de um maior grau de institucionalização exercido pelo maior número de Estados envolvidos, para tornar concreta $e$ eficaz a defesa de suas soberanias. A recente criação de tribunais híbridos atesta, a nosso ver, a habilidade dos governos africanos, apoiados por atores não estatais, como as ONGs de defesa dos direitos humanos, de assumir a responsabilidade de julgar seus tiranos e finalmente lutar contra a impunidade. 
Antes de estudar as duas experiências de tribunos híbridos que surgiram na África, o Tribunal Especial para a Serra Leoa (2.2) e as Câmeras Africanas Especiais (2.3), abordaremos generalidades sobre essas jurisdições sui generis (2.1).

\subsection{Generalidades}

As jurisdições penais internacionais multiplicaram-se nessas últimas décadas. Trata-se de jurisdições sui generis que constituem uma "terceira geração das jurisdições penais internacionais" (BRICHAMBAUT; et alii, 2011, p. 260), que surgiram após a $2^{\mathrm{a}}$ Guerra Mundial e, sobretudo, a partir dos anos 90 . Foram implantadas para reprimir os crimes internacionais peculiarmente atrozes perpetrados em grande escala. ${ }^{8}$ Exercem uma função judiciária. Normalmente, sua composição é mista: seus órgãos são formados de juízes da nacionalidade do Estado onde o processo se realiza e de magistrados internacionais, garantia da imparcialidade da corte. Sediam-se frequentemente no Estado do território do qual os fatos aconteceram e são competentes para julgar os fatos incriminados tanto pela legislação nacional do país envolvido quanto pelo direito internacional. Se todas têm uma dimensão internacional quanto a sua composição, seu grau de internacionalização varia. Seu sucesso difere em função da sua independência e imparcialidade, assim como do grau de cooperação que o Estado do qual ela depende lhe concede. A experiência demonstra que é sempre difícil conciliar diplomacia e justiça penal internacional.

De modo geral, os tribunais mistos ou híbridos visam, em primeiro lugar, abranger crimes que aconteceram antes de 2002, data da entrada em vigor do Estatuto de Roma de 1998 (pois o TPI de caráter permanente não tem competência retroativa) ou não entram no campo de definições dos crimes internacionais ou, em terceiro lugar, responder a certas críticas endereçadas aos tribunais ad hoc e ao TPI. O custo elevado, a lentidão dos processos e o afastamento dos magistrados das realidades locais e das sociedades afetadas pelos crimes são apontados como os principais entraves a uma justiça internacional eficaz. Para o continente africano, porém, a maior causa de rejeição da justiça penal internacional é o pretendido "afrocentrismo" do TPI.

O regionalismo africano em direito internacional penal cristaliza dois fenômenos inovadores: a jurisdicionalização e a penalização na ordem continental. O primeiro movimento que consiste na intervenção de juízes internacionais no tratamento dos conflitos ou o desenvolvimento da resolução jurisdicional das controvérsias internacionais é relativamente recente no direito da UA, que até agora privilegiava os meios diplomáticos ou não contenciosos. O segundo, entendido como o desenvolvimento de uma dinâmica penal, constitui uma revolução para a ordem jurídica continental, pois as organizações pan-africanas, de modo geral, sempre foram reticentes a usar mecanismos sancionadores. Em resumo, a justiça penal internacional, desde os anos 90, perturba frontalmente as regras oriundas de um direito internacional clássico ainda bem ancorado nas mentalidades africanas e torna o TPI o bode expiatório dos que não têm interesse na mutação do direito das gentes.

O continente africano é rico em experiências alternativas à justiça penal universal para adaptá-la às expectativas locais: a primeira jurisdição híbrida, quer dizer, tribunais internos internacionalizados, é o Tribunal Especial para a Serra Leoa, que sancionou o sanguinário expresidente da Libéria, Charles Taylor, e a segunda é ilustrada pelas Câmaras Africanas Extraordinárias (CAE), que condenaram recentemente o ex-ditador chadiano Hissène Habré.

\subsection{Tribunal Especial para a Serra Leoa (SCSL): o tribunal híbrido pioneiro}

A Serra Leoa, pequeno país da África Ocidental, foi o local de uma guerra civil sangrenta que começou em 1991 e terminou dez anos depois. O sistema judiciário de Serra Leoa, completamente exangue após anos de guerra civil, não era capaz de julgar os responsáveis dos atos de crueldade e o TPI não estava competente para julgar, pois as infrações internacionais foram cometidas antes de 2002.

Em 1999, o governo - sequioso de justiça, mas incapaz de assumir sozinho os processos -, junto com os rebeldes da Frente Unida Revolucionário (United Revolutionary Front, RUF) - sob a conduta de Foday Sankoh -,

8 À exceção do Tribunal Especial para o Líbano (TSL segundo o acrônimo francês), que apresenta várias singularidades. Com a Resolução n. ${ }^{\circ}$ 1757, de 30 de maio de 2007, o CS/NU, agindo em virtude do capítulo VII da Carta, implantou o TSL, após ter criado uma Comissão de Inquérito Internacional Independente (Resolução n. ${ }^{\circ}$ 1595). A constituição dessa jurisdição é fruto de um acordo firmado pelo governo libanês e a ONU no início de 2007. O TSL é encarregado de investigar e julgar os responsáveis do atentado do dia 14 de fevereiro de 2005, que matou o ex-premiê Rafic Hariri, e outros atos terroristas que ocorreram no Líbano posteriormente ao $1^{\circ}$ de outubro de 2004 . Esse tribunal, sediado em Haia, para fugir das pressões, influências e ameaças que poderiam se manifestar no Líbano, composto de juízes nacionais e magistrados estrangeiros, aplica exclusivamente o direito penal libanês. Seu campo de competência material exclui toda infração internacional e se insere em uma lógica de estabilização da paz. V. o site oficial do TSL. Disponível em: https://www.stl-tsl.org/fr/about-the-stl. Acesso em: 06 ago. 2019. 
e o representante especial do secretário-geral das Nações Unidas - todos preocupados com a estabilização da região, assinaram o Acordo de Paz de Lomé, que concedia a anistia aos rebeldes da RUF e criava uma Comissão da Verdade e da Reconciliação, encarregada de listar as violações ao direito internacional humanitário. Logo depois, a RUF retomou as hostilidades, tendo como alvo civis, e sequestrou 500 soldados da força de manutenção da paz da ONU. F. Sankoh foi capturado pelas forças governamentais, e o governo britânico tomou a iniciativa de instaurar uma ação judicial contra os criminais de guerra (ORGANISATION DES NATIONS UNIES, 2002).

Em uma carta do dia 12 de junho de 2000, endereçada ao secretário-geral das Nações Unidas, o ganês Kofi Annan, o presidente de Serra Leoa, Ahmad Tejan Kabbah, solicitou o apoio da organização internacional para criar um tribunal especial encarregado de julgar F. Sankoh e outros dirigentes da RUF pelos crimes cometidos contra o povo de Serra Leoa e os capacetes azuis. No seu quinto relatório sobre a missão das NU em Serra Leoa, submetido no 31 de julho de 2000 ao CS/NU (S/2000/751), K. Annan declarou, após consulta dos interessados, que os representantes do governo de Serra Leoa e as ONG privilegiavam um tribunal nacional dotado de um forte componente internacional e que seria competente para julgar os crimes de genocídio, crimes contra a humanidade e crimes de guerra, assim como os crimes contemplados pelo direito interno. Na Resolução n. ${ }^{\circ} 1315$, de 14 de agosto de 2000, o CS/NU confiou ao secretário-geral a missão de negociar um acordo com o país envolvido, com a finalidade de criar um "tribunal especial independente". As negociações demoraram mais de um ano para determinar as opções de financiamento, os crimes e sua definição e, enfim, a categoria das pessoas abrangidas pelo foro do tribunal em questão. Com efeito, os redatores do futuro ato constitutivo precisavam tomar em consideração as dificuldades encontradas pelos tribunais penais internacionais ad hoc e inventar uma jurisdição que pudesse conciliar princípios potencialmente contraditórios - o de soberania, relativo aos particularismos do sistema jurídico local, e o de respeito aos direitos humanos, quer dizer, a luta contra a impunidade.

O Tribunal Especial para a Serra Leoa foi finalmente criado por um acordo firmado entre a ONU e o governo de Serra Leoa, em 16 de janeiro de 2002. Sediado em Freetown, ${ }^{9}$ inaugura uma justiça in situ, próxima da população envolvida e concentrada "nos que carregam a maior responsabilidade", segundo a expressão do Ato constitutivo, e por isso mais eficaz que a instaurada para Ruanda. Trata-se de uma jurisdição mista, associando magistrados locais e juízes oriundos, principalmente, dos países de Estados anglófonos da África Ocidental. São visadas as "pessoas que assumem a responsabilidade maior das violações graves do direito internacional humanitário e do direito de Serra Leoa desde o 30 de novembro de 1996", como o Estatuto o determinou.

É competente para julgar os crimes contra a humanidade, as graves violações do artigo 3 comum das Convenções de Genebra, os ataques deliberados contra o pessoal de assistência humanitária ou de manutenção da paz, o alistamento de crianças nas forças ou grupos armados e os aspectos particulares do direito de Serra Leoa, visando as agressões sexuais contra as raparigas e execuções. O crime de genocídio não entra no rol das competências do SCSL por falta de provas de que os crimes foram perpetrados em razão da nacionalidade, etnia, raça ou religião das vítimas.

Trata-se de uma jurisdição híbrida, pois associa o direito internacional e o direito nacional (art. 3 do Estatuto do SCSL), o que a diferencia dos TPII e TPIR. Pessoas de Serra Leoa trabalham com procuradores, advogados e juízes estrangeiros. ${ }^{10}$ Sob a égide do procurador britânico $G$. Desmond de Silva, o tribunal inculpou 13 pessoas de violação das Convenções de Genebra, membros de todas as partes beligerantes, o que deixou pressagiar que o risco de uma "justiça dos vencedores" seria evitado.

Apesar de sérias dificuldades financeiras - seu orçamento era alimentado somente por contribuições estatais voluntárias -, pronunciou uma dezena de decisões visando chefes de guerra locais. Em 30 de maio de 2012, condenou a 50 anos de prisão o ex-presidente da Libéria, Charles Taylor, que envolveu a África Ocidental em um conflito mortífero: os combatentes, a maioria crianças-soldado recrutadas pela força e drogadas, foram acusados das mais cruéis chacinas, mutilações, estupros e atos de canibalismo. ${ }^{11}$ Além dos feridos, foram contabilizados mais de 50.000 pessoas mortas e 2 milhões de deslocados (um quinto da população) (UNICEF, 2003; INTERNATIONAL CRISIS GROUP, 2001). A sentença foi confirmada em apelo no ano seguinte. Suas atividades encerraram em 2013.

Exceto para o julgamento do líder Charles Taylor, a sede foi deslocada para Haia por motivo de segurança.

10 Três dos cinco juízes foram nomeados pelo governo local e os outros juízes foram originários da Áustria, do Canadá, dos Camarões, da Irlanda do Norte, da Uganda, da Samoa e do Sri Lanka.

11 Horrores da guerra ilustrada pelo filme hollywoodiano de E. ZWICK, Diamante de Sangue, de 2006. V. também o filme distribuído pela Netflix: Beasts of No Nation (2015), inspirado do romance escrito por U. Iweala, escritor nigeriano-norte americano. Apesar de os fatos ocorrerem em um país não identificado, eles são bem semelhantes ao que aconteceu na Serra Leoa na década 90. 
Bem como os tribunais ad hoc antecessores, o SCSL participou da evolução das normas de direito internacional. Se o TPIR foi o primeiro a incorporar o estupro nos elementos da definição do crime contra a humanidade, o Tribunal de Freetown inovou também ao qualificar como crime de guerra o alistamento de crianças-soldado. Outra diferença com os tribunais internacionais consiste em, caso necessário, o tribunal híbrido poder inspirar-se em soluções locais para preencher as lacunas das normas internacionais. Assim, foram aplicadas leis de Serra Leoa de $1861 \mathrm{e}$ 1926 para julgar atos de destruição voluntária de propriedade e de agressões sexuais contra raparigas. Todavia, as regras processuais e de provas aplicáveis são as definidas pelo TPIR, com possibilidade de se inspirar no Código de Processo Penal de Serra Leoa de 1965 (art. 14 do Ato). Não obstante, o Tribunal em tela adotou algumas regras específicas, como a autorização para os juízes exercerem sua função fora de Serra Leoa, para sessão a porta fechada e predileção pela prova oral (PERRIELLO; WIERDA, 2006). Uma abordagem específica em prol das crianças foi elaborada pelo Tribunal para oferecer proteção e confidencialidade aos menores envolvidos. Outro aspecto inovador, fonte de inspiração para os tribunais subsequentes, foi o Bureau da Defesa: o sistema associou um grupo central de defensores internos a um sistema tradicional de lista de advogados individuais suscetíveis de serem afetados a cada réu. A ideia era de juntar advogados experimentados, nacionais e estrangeiros.

Infelizmente, o Estatuto do tribunal africano não resolveu o problema da entrega dos acusados contra a vontade dos Estados que os abrigam. Assim, Gana e Nigéria resistiram, atrasando consideravelmente as atividades do tribunal híbrido (ARSENEAULT, 2005, p. 20).

O SCSL participou obviamente do processo de reconciliação da Serra Leoa, hoje um dos países mais ricos do continente, onde fatos raros aconteceram: eleição democrática de Ellen Johnson Sirleaf, primeira mulher presidente; no fim do seu mandato, após outras eleições democráticas, transferência pacífica do poder. Nota-se, entretanto, que o líder $\mathrm{C}$. Taylor continua impunido pelos atos cometidos no seu próprio país. Na Libéria, houve somente uma Comissão de Verdade e Reconciliação, estabelecida após a guerra, que tentou esclarecer os crimes. Suas recomendações não foram seguidas, lamenta o antigo procurador do Tribunal, Alain Werner (CIVITAS MAXIMA, s. d.), talvez por preconizar, entre outras medidas, banir da vida política a então presidente e prêmio Nobel da Paz E. Johnson-Sirleaf, ex-cúmplice do "senhor de guerra".

Em resumo, o legado da jurisprudência do tribunal é múltiplo. A decisão da Câmara de Apelo do dia 31 de maio de 2004 (SPECIAL COURT FOR SIERRA LEONE, 2004a) manteve que o recrutamento e alistamento de crianças de menos de 15 anos é crime, pelo qual os réus deviam ser julgados penal e individualmente. Referiu-se à jurisprudência da principal jurisdição da ONU, a Corte Internacional de Justiça, para invalidar a anistia concedida pelo Acordo de Paz de Lomé e resolver que eles não se aplicam para cobrir os crimes internacionais (SPECIAL COURT FOR SIERRA LEONE, 2004b).

Além de servir de modelo para outras partes do mundo (Kosovo, Timor-Leste, Camboja, Iraque...), ${ }^{12}$ esse Tribunal demonstrou que os africanos, com o apoio da sociedade internacional estatal e civil, podiam assumir suas responsabilidades. Foi esse modelo de justiça híbrida que foi recomendado pela UA para julgar as violações aos direitos humanos cometidas no Darfur. Porém, diante da falta de cooperação do governo sudanês, o projeto não foi ainda materializado e os altos responsáveis políticos suspeitos de crimes internacionais estão ainda impunes.

O julgamento do ex-ditador chadiano teve mais êxito. As Câmeras Extraordinárias constituem o segundo exemplo de criação de uma jurisdição interna internacionalizada que parece conciliar melhor os princípios de soberania com o princípio de direitos humanos.

\subsection{Câmaras Africanas Extraordinárias: prelúdio a uma instância jurisdicional penal africana}

Talvez por ser um dos primeiros ex-chefes de Estado a não mais gozar da imunidade de jurisdição e execução, por não ter tecido relações de lealdade com seus pares ou por se ter distinguido pela particular brutalidade da sua política repressiva que o tornou pestífero, Hissène Habré, ex-presidente do Chade, não se beneficiou da solidariedade incondicional dos autocratas africanos que protegeu durante décadas autores de infrações internacionais, como os chefes de Estado queniano ou sudanês. Ao contrário, seu caso é um dos raros que conseguiu concentrar nele os

12 O Tribunal Especial Iraquiano inspirou-se, por exemplo, na simplificação das regras processuais do SCSL em comparação com as dos TPII ou TPIR, notadamente da preeminência dada às declarações das testemunhas, menos pesadas que as provas literais e volumosas. 
esforços uníssonos de instituições nacionais, regionais e universais, públicas e privadas, e, finalmente, oferecer uma oportunidade de arquitetar um sistema jurisdicional original e inédito (SAWADOGO, 2014, p. 105), apto a satisfazer não só os defensores dos direitos humanos como as autoridades africanas muito apegadas à sua soberania.

Em 2000, sete vítimas chadianas e a ONG Association des victimes de crimes et répressions politiques au Tchad (AVCRP) apresentaram queixa por atos de tortura e crimes contra a humanidades contra H. Habré, no Senegal, país onde o ex-presidente do Chade achou asilo depois da sua fuga. Denunciadas desde muitos anos por associações nacionais e internacionais, como pela Amnesty International (1990) e, em particular, pelo Conselheiro Reed Brody, da ONG Human Rights Watch (s. d.), as exações cometidas pelo regime chadiano durante a presidência de H. Habré, entre 1982 e 1990, foram além do revelado pelas instâncias internacionais. ${ }^{13}$

Conforme relata o julgamento da jurisdição híbrida, que condenou $\mathrm{H}$. Habré (CHAMBRE AFRICAINE EXTRAORDINAIRE D'ASSISES, 2016), a criação das CAE no seio das jurisdições senegalesas é o resultado de um longo processo. No dia 3 de fevereiro de 2000, o juiz de instrução do Tribunal Regional de Dakar aceitou sua competência, colocou o ex-chefe de Estado em prisão domiciliar e o inculpou de cumplicidade por crimes contra a humanidade e atos de tortura e de barbárie. Decidindo sobre um recurso interposto pelo réu, a Corte de Apelo de Dakar anulou o processo por incompetência do juiz acionado. Ao condenar o acusado por crimes contra a humanidade, infração ausente do direito penal senegalês, a sentença de primeira instância violou o princípio de legalidade dos delitos e das penas. Decidiu, também, que as jurisdições nacionais não podiam conhecer fatos de tortura cometidos por um estrangeiro em território estrangeiro, não importando a nacionalidade das vítimas. Na sua decisão do dia 20 de março de 2001, a Cour de Cassation do Senegal manteve a anulação da decisão de primeira instância ao confirmar a inexistência de uma lei de competência universal no país. Longe de se considerarem desalentadas, as vítimas insistiram e abriram duas novas frentes para obter justiça: uma nacional, na Europa, e outra internacional.

Um belga de origem chadiana acionou, em novembro do ano seguinte, as jurisdições da Bélgica, em aplicação da sua lei de competência universal. Após investigações efetuadas in loco, o juiz europeu emitiu, em 2005 , um mandado de detenção internacional contra $\mathrm{H}$. Habré, acusado de violações graves ao direito internacional humanitário, atos de tortura, crime de genocídio, crimes contra humanidade e crimes de guerra. O Senegal, alegando, em conformidade com o direito internacional clássico, a qualidade do chefe de Estado no momento dos fatos imputados, negou a extradição do déspota chadiano.

Paralelamente a essas ações no patamar estatal, as vítimas, apoiadas pelas ONGs de defesa aos direitos humanos (HUMAN RIGHTS WATCH, 2001), iniciaram um plano de ação no palco internacional que surtiu êxito. Assim, o Comitê das Nações Unidas contra a Tortura, acionado em 2001 para contestar a decisão de incompetência dos juízes senegaleses, condenou o Senegal, membro signatário da Convenção contra a Tortura de 1984, pelo não respeito às suas obrigações convencionais. O Comitê convidou-o a tomar as medidas necessárias para estabelecer sua competência relativa aos crimes visados pela Convenção e submeter o caso Habré a suas autoridades jurisdicionais ou aceitar as demandas de extradição (COMITÉ DES NATIONS UNIES CONTRE LA TORTURE, 2006).

Em 2 de julho de 2006, a UA (2006, §§ 3, 4 e 5), acionada pelo Senegal, adotou recomendação reconhecendo sua competência para julgar os crimes atribuídos ao expresidente chadiano e, na ausência de um órgão judiciário regional apto a assumir seu julgamento, sentenciar o interessado "em nome da África". Seguindo as orientações do Comitê contra a Tortura e da UA, o país resolveu modificar sua legislação para que suas jurisdições pudessem julgar os crimes internacionais e também os critérios de competência, para que permitissem abranger os crimes cometidos por $\mathrm{H}$. Habré no Chade. Uma emenda modificou igualmente a constituição nacional ao abrir uma exceção ao princípio de não retroatividade da lei penal para tais crimes. Apesar da nova ação por 14 vítimas perante o ministério público de Dakar, nenhum processo judiciário foi iniciado nessa nova base legal.

$\mathrm{Em} 1^{\circ}$ de outubro de 2008 , os advogados de $\mathrm{H}$. Habré, em reação às modificações legislativas e constitucionais, acionaram a Corte de Justiça da Comunidade dos Estados da África Ocidental (CEDAO), fundamentados em que estas violariam os princípios de irretroatividade da lei penal, de igualdade perante a lei e do direito a um processo equitativo. Todos os argumentos foram rejeitados pela Corte na sua decisão do dia 18 de novembro de 2010, concluindo que a implantação do mandato da UA respeitava o "costume internacional" que "tem hoje o hábito de criar jurisdições ad hoc ou especiais” (COUR DE JUSTICE DE LA CEDEAO, 2010).

13 O sistema repressor baseava-se em um serviço especial encarregado da segurança interior e exterior: a Direção da Documentação e da Segurança (DDS), financiada pelos norte-americanos, diretamente ligada à presidência, tornou-se o símbolo do arbítrio e do terror. Essa polícia política, sob as ordens do presidente, perpetrou crimes horríveis. Segundo a Comissão de Inquérito criada por decreto, em 1990, no seio da Corte de Apelo de N'Djamena, foram identificados 10.000 oponentes e membros das suas famílias executados, após terem sido torturados nas piores formas. 
Enfim, no início de 2009, a Bélgica acionou a ClJ, alegando a violação pelo Senegal da sua obrigação de perseguir ou extraditar H. Habré. No dia 20 de julho de 2012, a CIJ (2012) condenou o país africano por ter violado as obrigações que lhe impõe o artigo 7 da Convenção contra a Tortura e, como as três outras instituições internacionais anteriores exigiram, o obrigou a submeter o caso do ex-tirano chadiano a suas autoridades competentes se ela não o queria extraditar.

O conjunto dessas decisões judiciárias e políticas conduziu logicamente o Senegal e a UA a empreender negociações para determinar o quadro institucional de um processo. É assim que, no dia 22 de agosto de 2012, os dois assinaram o Acordo instituindo as Câmaras Africanas Extraordinárias no seio das jurisdições senegalesas, encarregadas de julgar os principais responsáveis pelos crimes internacionais cometidos no Chade entre 1982 e 1990. O tratado foi ratificado pelo Presidente da República em dezembro e promulgada uma segunda lei, transpondo o Acordo para a ordem jurídica senegalesa. Um decreto do Presidente autorizou, em janeiro de 2013, a Comissão da UA a nomear os magistrados senegaleses compondo as CAE. O Conselho Constitucional do Senegal, acionado pela defesa, considerou que o Acordo não violava nenhuma disposição da Carta Magna e afirmou o caráter internacional da jurisdição: os magistrados de nacionalidade senegalesa "não têm por missão fazer a justiça em nome do povo senegalês, mas atuar em qualidade de uma jurisdição internacional ou mista especializada", cuja base é o Acordo, criando as CAE em conformidade com a decisão da Corte de Justiça da CEDEAO de 2010, já citada. A Câmara que julgou $\mathrm{H}$. Habré foi composta de três juízes e presidida por Gberdao Kam, magistrado do Burkina Faso, que ocupou várias funções no ministério de Justiça do seu país e atuou como juiz do TPIR.

O Estatuto das CAE fixou a composição e as regras de funcionamento das câmaras, as normas aplicáveis, quer dizer, "o direito penal internacional", consistindo nas convenções internacionais ratificadas pelo Chade e pelo Senegal na época da comissão dos fatos, além do direito consuetudinário internacional e, para preencher as lacunas, "o direito senegalês pertinente". As pessoas acusadas não podem se eximir das suas responsabilidades ao alegar sua qualidade oficial, também de "chefe de Estado". As regras de competência ratione loci (Chade), ratione temporis (1982-1990) e ratione materiae (crimes de genocídio, crimes contra a humanidade e crimes de guerra e tortura) ${ }^{14}$ respeitam o modelo dos tribunais penais internacionais ad hoc pioneiros.

$\mathrm{H}$. Habré foi o único acusado julgado pelas CAE, porque as investigações se revelaram infrutíferas para acusar outros suspeitos ou pela recusa do Estado chadiano (hoje governado por Idriss Deby, ex-chefe do exército do acusado) de executar os mandados de detenção internacionais. Logo no início, três advogados, nomeados pela Câmara, assumiram a defesa do ex-presidente chadiano, que nunca reconheceu a legalidade e legitimidade do tribunal híbrido, equiparando as CAE a um "serviço administrativo" (CHAMBRE AFRICAINE EXTRAORDINAIRE D’ASSISES, 2016, § 62). Os bens e contas bancárias do acusado foram penhorados. Os juízes do tribunal de Dakar demonstraram uma grande solicitude a respeito das garantias processuais, em particular o princípio do contraditório, apesar do comportamento rebelde do chadiano. ${ }^{15}$

Finalmente, a decisão das CAE de 31 de julho de 2016 declarou H. Habré culpado "dos crimes contra a humanidade, de estupro, de escravidão forçada, de homicídio voluntário, de prática maciça e sistemática de execuções sumárias, de sequestros de pessoas seguidos de desaparecimento, de tortura e atos desumanos", do "crime autônomo de tortura", de "crimes de guerra de homicídio voluntário, de tortura, de tratamentos desumanos, e de detenção ilegal", assim como de "crimes de guerra de assassino, tortura e de tratamentos cruéis". Condenou o ex-chefe de Estado africano à prisão perpétua. Essa decisão, muito detalhada (mais de 530 páginas), foi fundamentada nas leis senegalesa e francesa, nos diplomas e na jurisprudência internacionais. Foram citadas decisões do TPI, da Corte Europeia dos Direitos Humanos e das Câmeras Extraordinárias no Seio dos Tribunais Cambojanos (CECT), que serviram de modelo de inspiração para as CAE.

No dia 29 de julho de 2016, outra decisão das CAE condenou o preso a indenizar as vítimas de "estupro" e de "detenção arbitrária", os "prisioneiros" e as "vítimas indiretas" (entre € 15245 e $€ 30490$ por vítima). No dia 27 de abril de 2017, a sentença foi confirmada em apelo.

14 Os juízes declararam-se incompetentes para julgar os casos de pilhagem de bens do Estado chadiano pelo réu, sob a alegação de que nenhum prejuízo indicado resultava de um dos crimes visados no Estatuto.

15 Durante as audiências, o réu recusou-se a aparecer, falar e a tirar seu turbante, o que criou vários incidentes durante o desenrolar do processo. Enquanto foram ouvidas mais de 1000 testemunhas indicadas pela acusação, a defesa não forneceu nenhuma lista de pessoas a serem ouvidas; várias visitas foram organizadas nos locais das valas comuns, mas sem sua colaboração. 
Esse primeiro processo, no qual um antigo chefe de Estado é julgado pela jurisdição de um outro país por violações dos direitos humanos, foi saudado como "processo exemplar" pelo coletivo das ONGs (BRODY, 2013). Ben Kioko, ex-juiz no TPIR, ex-conselheiro jurídico da UA e idealizador das CAE, aplaudiu o processo, ilustrando, segundo suas palavras, o "maior sucesso coletivo africano para combater a impunidade" (TILOUINE, 2015).

É prematuro, hoje, dizer se as CAE constituirão um precedente ou ficaram isoladas nos anais das jurisdições penais internacionais como uma anomalia na paisagem criminal mundial. Porém os africanos parecem considerar que essas Câmaras poderiam abrir novos horizontes à luta contra a impunidade e oferecer uma solução ao impasse resultante dos atritos entre o TPI e a UA. Sem dúvida, elas demonstram que a justiça continental está em movimento.

As CAE tiveram o grande mérito de terem constituído as premissas, o "embrião" (NGUEFEU, 2015, p. 129) de um projeto mais ambicioso, que é a criação de uma instância jurisdicional penal africana, que pode oferecer não um meio político que visa burlar a obrigação internacional de reprimir os crimes internacionais, mas uma alternativa pertinente para constituir uma contribuição importante da África ao desenvolvimento do direito internacional penal: o tribunal penal internacional regional permanente.

\section{0 tribunal penal internacional regional permanente}

As experiências acumuladas pelas jurisdições criminais que atuaram nas últimas décadas na África - TPIR, primeiros tribunais internos internalizados, SCSL, lei de competência universal senegalesa e CAE - orientaram a UA a criar solução própria e mais apropriada à realidade africana. Com efeito, essas iniciativas apresentam desvantagens, como de serem ad hoc (o que significa que privilegiam a dimensão reparadora sobre a preventiva) e onerosas. Além disso, a África precisa lutar contra a proliferação das organizações regionais que dificilmente ela consegue assumir financeiramente sozinha. Para remediar essas dificuldades, surgiu a ideia de optar para uma solução inovadora: a criação de uma seção especializada no seio de uma jurisdição preexistente, a Corte Africana de Justiça, dos Direitos Humanos e dos Povos (CAJDH), criada pela UA, organização regional que abriga a totalidade dos Estados africanos.

A CAJDH, sediada em Arusha (Tanzânia), é o fruto de uma fusão entre a Corte de Justiça da UA, criada pelo Protocolo de Maputo em 2002 (ainda não em vigor), e a Corte Africana dos Direitos Humanos, implantada pelo Protocolo de Ouagadougou de 1998 (que entrou em vigor em 2006). Porém vale ressaltar que o Protocolo de Sharm-el-Sheikh (Egito) de 2008, que operou essa fusão, não entrou em vigor por falta de ratificações suficientes. Hoje, essa instância é dividida em duas seções: a Seção dos Assuntos Gerais, que corresponde à Corte de Justiça Africana, e a Seção dos Direitos humanos, que assume as atribuições da Corte Africana dos Direitos Humanos e dos Povos. A primeira é encarregada de dirimir as controvérsias entre os Estados africanos (como a ClJ), e a segunda constitui uma jurisdição regional dos direitos humanos (como a Corte Europeia ou Interamericana dos Direitos Humanos) (CAJDH, s. d.).

O Protocolo de Malabo, adotado em junho de 2014, estabeleceu uma terceira seção, a de direito internacional penal. Esta é uma instância permanente, contrariamente às CAE, limitadas no tempo ou no espaço. Todavia não se trata de uma jurisdição penal independente, mas de uma instância penal no seio da jurisdição geral africana. A criação desse tribunal responde à necessidade de atender melhor às aspirações do continente. Por exemplo, a competência ratione materiae abrange, além dos crimes internacionais, e infrações não previstas no Estatuto de Roma, como crime relativo à mudança anticonstitucional de governo, ao emprego de mercenários, à corrupção, à lavagem de dinheiro, ao tráfico de pessoas, ao tráfico ilícito de entorpecentes e resíduos perigosos, e à exploração ilícita dos recursos naturais. Esses crimes não são exclusivos do continente africano, mas são pragas que impedem seu desenvolvimento e sua estabilidade. O regionalismo acha aqui sua razão de ser e pode contribuir de maneira significativa para o desenvolvimento progressivo do direito internacional penal geral. Isto porque, se os crimes inéditos têm uma ressonância particular na África, como o golpe de Estado, a modificação forçada da constituição para se manter no poder ou a corrupção, essas infrações poluem também a vida política dos outros países em todos os continentes, incluindo a América Latina.

Outra diferença entre o Protocolo Malabo e o Estatuto de Roma, que concentra a maioria das reações da doutrina e das ONG de defesa dos direitos humanos, é a questão das imunidades. Como essa corte permanente não é ainda operacional - em particular por causa de Robert Mugabe, chefe de Estado do Zimbabué de 1980 até 
2017 e então presidente da UA, que obrigou a introduzir um artigo garantindo a imunidade pessoal para os chefes de Estado e funcionários de alto escalão -, é difícil ainda tecer considerações sobre seu futuro funcionamento.

Podemos adiantar, todavia, que um dos problemas que essa jurisdição deverá enfrentar é o seu lugar no arcabouço da justiça penal internacional e, em particular, sua coexistência com o TPI. Como no modelo das relações entre a instância universal e os sistemas nacionais, a articulação dos vínculos entre a futura $3^{\circ}$ seção da CAJDH e o TPI operar-se-á sob o prisma dos princípios de complementaridade e de subsidiariedade. A jurisdição universal torna-se competente somente em caso de inércia dos tribunais nacionais ou regionais. Ocorrerão, com certeza, problemas de interpretação, como existem hoje, para saber se a justiça regional responde ou não às exigências internacionais de legalidade e imparcialidade para fazer justiça. Pensamos nas querelas entre o TPI e as autoridades da Costa de Marfim (que se recusaram a entregar Simone Gbagbo, esposa do ditador Laurent Gbabgo, que foi julgado pela jurisdição criminal internacional) ou as autoridades da Líbia (a respeito da entrega do filho de Muamar Khadafi, Saïf Al-Islam).

As opiniões da doutrina especializada são bem divididas sobre o destino dessa corte. Uma parte mais otimista, representada pelo professor da universidade de Yaoundé, Augustin Nguefeu (2015, p. 129), prefere dar chance ao continente africano de assumir suas responsabilidades. Nesse sentido, ele cita o artigo 461.3 do Protocolo em excerto, que prevê a possibilidade para a nova instância africana de "cooperar com as cortes internacionais": "assim, à luz do princípio geral de complementaridade, este artigo se revela ser uma mão estendida para uma coabitação salutar entre o sistema regional africano e o TPI" (tradução livre). Outra parte, mais cética, enxerga essa nova iniciativa como um meio para burlar suas obrigações internacionais (WUILBERCQ, 2017). Podemos citar as palavras do secretário-geral da Federação Internacional das Ligas dos Direitos Humanos, para quem a implantação de tribunais regionais na África não deveria ser "uma maneira de jogar um véu pudico sobre as impotências, covardias ou incapacidade da comunidade internacional para prevenir e cessar os conflitos" (apud ROBERT, 2003; tradução livre).

Preferimos optar pela primeira tendência, porém sabemos que a nova corte penal africana deverá enfrentar vários desafios. O primeiro é o da operacionalidade da jurisdição penal regional. Vale lembrar que à UA falta experiência na implementação de instituições. Nascida nos anos 60 , a organização nunca dispôs de uma jurisdição geral. A primeira instância jurisdicional é a Corte Africana dos Direitos Humanos e dos Povos, criada pelo Protocolo de Ouagadougou em 1998. Demorou cinco anos para entrar em vigor e pronunciou sua primeira decisão somente em 2009. O projeto da criação da CAJDH emergiu em 2000 e ainda não foi concretizado na sua primeira versão da união das duas: a CADH e a CJA. A adjunção de uma terceira seção penal não milita em prol de menos letargia que caracteriza a UA. O segundo desafio é a eficácia da jurisdição continental penal permanente. De um lado, as discórdias entre a UA e o TPI ou a cláusula sobre a imunidade dos chefes de Estado em exercício não deixam augurar um consenso firme para perseguir todo criminoso e garantir o financiamento de um processo equitativo. Do outro lado, a experiência do Tribunal Especial para a Serra Leoa ou das CAE comprovam que podemos ter esperança no surgimento de um regionalismo em direito internacional africano. $O$ autor burquino Abdoulaye Soma (2015, p. 34) resume os pontos que criavam obstáculo à luta contra a impunidade na África nestes termos:

Sabemos que as fricções entre a África e o TPI estão vinculadas à questão da imunidade dos chefes de Estado e de governo. Todavia, a União Africana parece desejar menos sua impunidade que criticar seu julgamento por jurisdições extra-africanas, sob iniciativa extra-africana e durante o período do exercício de suas funções oficiais (tradução livre).

Logicamente, essa nova corte deveria permitir contornar esses obstáculos e atender às expectativas aparentemente contraditórias dos líderes africanos e dos seus povos.

O outro ponto nevrálgico é o financiamento de uma justiça penal eficaz. Sabemos as dificuldades financeiras dos Estados africanos e dos problemas que a UA atravessa. O funcionamento do TPIR necessitou de um orçamento anual médio de 100 milhões de dólares. O do TPI aproxima-se desse número. O processo de H. Habré foi estimado em 30 milhões de dólares e foi difícil juntar um terço do orçamento. Nas últimas cúpulas da UA, um dos temas abordados foi justamente a política de custo da organização regional e de promoção da sua independência. Com efeito, a maior parte do orçamento da "organização estrangeira", segundo a expressão irônica de Désiré Assoghavi da OXFAM (citado por GWET, L'IDÉAL, 2016), vem de doações privadas (da União Europeia, dos Estados Unidos, da China e do Banco mundial). O Presidente da Comissão da UA, o chadiano Moussa Faki Mahamat, chamou a atenção dos 
colegas que não pagam suas contribuições ${ }^{16}$ nesses termos: "Sem sua independência, a África não é nada. Com a independência, ela pode tudo" (citado por KOUHON, 2018). História cômica, se não fosse triste: em 2012, o exImpério Celeste construiu o prédio da sede da UA, "presente da China aos amigos da África", no valor de 200 milhões de dólares. Em janeiro de 2017, foi descoberta a espionagem pelo país doador, usando o sistema de informática instalado graciosamente por ele, com câmeras e microfones, durante a construção, nos muros e embaixo das mesas. Para evitar esses tipos de revezes, o então presidente da UA, o chefe de Estado ruandês Paul Kagamé, lançou sua política de melhoria da gestão e limitação dos abusos, como a redução das contribuições exteriores. "Esperamos que o voluntarismo da União Africana e seus membros superará o laxismo ambiente a pagar as contribuições para o funcionamento das organizações internacionais na África" (SOMA, 2015, p. 35; tradução livre).

O caminho da implantação da futura instância penal africana de caráter permanente será longo e semeado de obstáculos, mas podemos esperar, com o ex-presidente da UA, Alpha Condé (TILOUINE; KADIRI, 2018), que as crises africanas serão cada dia mais resolvidas pelos africanos. Como vimos, o exemplo do SCSL ou das CAE, que condenaram os ex-ditadores, respectivamente, da Serra Leoa, Charles Taylor, e do Chade, Hissène Habré, abriu uma onda de esperanças. Podemos citar como iniciativas nacionais recentes: a condenação à pena de morte à revelia do sanguinário tirano etíope M. Hailé Mariam, refugiado desde 1991 no Zimbabwe; a deposição dos chefes de Estado, em que eclodiram as "primaveras árabes" de 2011; a condenação à revelia a várias penas de reclusão perpétua do tunisiano Z. Al-Abidine Ben Ali, refugiado na Arábia Saudita, onde morreu em 2019; o julgamento do egípcio H. Moubarak, que arriscou a pena de morte em 2011 (mas foi finalmente liberado em 2017 pelo novo poder militar).

Outros chefes de Estado em exercício ou não foram ou estão também ameaçados de inculpação. ${ }^{17}$ Todos se beneficiam, por enquanto, da proteção dos países vizinhos que lhes oferecem o asilo e se recusam a extraditá-los, motivando sua decisão pela falta de confiança nas instituições judiciárias. Com esse movimento de africanização da justiça internacional penal, porém, é cada dia mais difícil para eles justificar a impunidade dos que causaram ou causam ainda sofrimentos a seus povos. Além dos autocratas citados, que, para se manter no poder e enriquecer, não tiveram medo de reprimir sua população e, às vezes, provocar guerras civis, as futuras CAE ou a terceira seção da CAJDH deverão resolver os casos: de R. Mugabe do Zimbabwe ou de Y. Jammeh da Gâmbia, que negociaram sua retirada do poder contra a promessa de deixar seu país, em 2017, sem serem inquietados com ações judiciárias; de M. Ravalomanana de Madagascar ou P. Johnson da Libéria, que se beneficiaram de um tipo de anistia informal; de J. Zuma da África do Sul, que se aproveitou da inércia da sociedade internacional, que prefere o status quo a um risco de instabilidade na região (BOUQUET, 2018).

\section{Conclusão}

É, com certeza, na dialética de manutenção das soberanias nacionais e de promoção de regras superiores destinadas a erradicar os comportamentos contrários ao direito que a justiça e a paz mundiais poderão prosperar, muito mais que no sacrifício geral e incondicional da independência dos países. Parece que o movimento de "africanização" da justiça penal internacional pode oferecer uma solução ao pretendido "afrocentrismo" do TPI. Mesmo que as objeções sobre o afrocentrismo do TPI possam ser facilmente refutadas, ${ }^{18}$ por serem exageradas e instrumentalizadas pelos autocratas para fugir das suas responsabilidades, elas não podem ser ignoradas. Há um verdadeiro problema no tocante à independência e ao respeito à soberania dos países africanos que mina a credibilidade e a legitimidade dessa jurisdição penal, como dos tribunais criminais ad hoc que o antecederam. Consideramos que as jurisdições de cunho universal, apesar das suas falhas, são e continuarão a ser organismos essenciais para concretizar os direitos humanos. Aliás, ao despertar a consciência dos Estados africanos para a necessidade de julgar seus criminosos, ao obrigar as organizações regionais a intervirem nesse processo de incriminação, as jurisdições universais preencheram seu papel. Com efeito, repetimos que o TPI, hoje o único em

\footnotetext{
Somente a África do Sul, Argélia, Egito, Nigéria e Líbia - substituída por Marrocos, que acabou de ingressar na UA-pagam hoje suas contribuições. A. Toumani Touré, refugiado no Senegal, foi julgado, porém depois inocentado, pelo crime de alta traição; F. Bozizé, ex-presidente da RCA, deposto em 2013, é ainda objeto de um mandado de prisão internacional emitido por seu país; B. Compaoré, ex-presidente burquino, expulso do poder em 2013 e refugiado na Costa do Marfim, é igualmente visado por 18 mandados de prisão internacionais.

18 A agressiva postura da administração do presidente Donald Trump contra o TPI, após a abertura de uma investigação sobre os crimes cometidos pelo exército norte-americano no Afeganistão (HALE, 2017), seria um argumento pertinente nesse sentido.
} 
vigor, não é o remédio ideal: seu papel, a nosso ver, não é de julgar todos os carrascos da terra, mas de estimular os Estados e blocos regionais a assumirem suas responsabilidades e a condenarem seus "monstros" nos moldes internacionais que ele e seus antecessores - TPII e TPIR - desenharam.

Conforme a teoria de interdependência complexa, defendida pelos autores norteamericanos Keohane e Nye $\mathrm{Jr}$, a regionalização da JPI, pela criação de jurisdições próprias ao continente, seria a melhor solução para defender as frágeis soberanias dos 55 Estados africanos. As novas iniciativas locais e regionais do continente abrem novas perspectivas para passar do criticado "afrocentrismo" a uma desejada "africanização" do direito internacional penal. A África, por ser a parte do mundo mais afetada pelo cometimento de crimes internacionais que chocam a consciência humana e por ser a terra de predileção do pluralismo jurídico, se mobiliza para tornar o princípio de subsidiariedade consagrado pelo Estatuto de Roma de 1998, efetivo através da criação de novos sujeitos internacionais. Inspiradas pelas jurisdições antecessoras ad hoc, como o TPII e o TPIR, e pelo TPI de caráter permanente, os atores locais e regionais tomaram a iniciativa de criar seus próprios organismos regionais, com suas próprias regras jurídicas, aptos a julgar seus criminosos de lesa-humanidade, nos moldes impostos, todavia, pela JPI. Vimos, por exemplo, que, em 2002, os africanos tomaram a dianteira ao criar uma corte híbrida, o Tribunal Especial para a Serra Leoa, que inovou em vários pontos e serviu de paradigma para outras partes do mundo e para a UA. Outra diligência na seara penal, sucedida, foi a criação, dez anos depois, das Câmaras Extraordinárias Africanas, que inspiram o continente e, talvez, servirão de prelúdio à criação de uma justiça penal africana.

A criação de uma seção penal permanente integrada no seio da jurisdição geral do continente, o Tribunal Africano dos Direitos do Homem e dos Povos, criada pela UA, é ambiciosa e está nos holofotes dos defensores dos direitos humanos do planeta, mesmo se o Protocolo de Malabo, adotado em junho de 2014, não entrou ainda em vigor (foi assinado por somente 15 Estados e nenhum deles o ratificou). Com efeito, a implantação desse tribunal responderia à vontade de "africanizar" a JPI para adaptá-la às exigências locais e atender melhor às aspirações do continente negro.

À guisa de considerações finais, gostaríamos de salientar que os tribunais penais africanos oferecem hoje, além de um novo direito descentralizado, não mais dominado pelo eurocentrismo, uma oportunidade para a comunidade internacional estimular uma reflexão sobre as funções e finalidades do direito penal internacional, e contribuem para nutrir esse novo ramo de direito com vocação "universal" de experiências locais e regionais, soluções alternativas que ele precisa para superar a crise que atravessa atualmente. Concluímos com as reflexões recentes de Achille Mbembe, confiadas ao jornal francês Le Monde (KODJO-GRANDVAUX, 2019):

Uma parte importante do futuro do planeta acontecerá na África. Esta não é apenas um enorme canteiro de obras, o epicentro de transformações de escala rápidas, abruptas e sem precedentes. É o laboratório vivo no qual as múltiplas figuras do mundo por vir já estão delineadas. Para nós que aqui vivemos e trabalhamos, esta viragem planetária da condição africana e a tendência para a africanização da condição planetária será o grande acontecimento filosófico, cultura e artístico do século XXI.

Pedimos autorização para acrescentar, ainda, os adjetivos "político" e "jurídico".

\section{Referências}

AFRICAN UNION. Withdrawal Strategy Document, Draft 2. Addis-Abeba, 12 jan. 2017. Disponível em: https:// www.cairn.info/revue-politique-africaine-2017-2-page-165.htm\#no4. Acesso em: 15 jan. 2021.

AMNESTY INTERNATIONAL. Amnesty International Report: 1990. Londres: Amnesty International Publications, 1990. Disponível em: https://www.amnesty.org/download/Documents/POL1000031990ENGLISH. PDF. Acesso em: 07 ago. 2019.

ARSENEAULT, M. Sierra Leone, de la justice à la réconciliation. Le Monde Diplomatique, Paris, out. 2005, p. 20. Disponível em: https://www.monde-diplomatique.fr/2005/10/ARSENEAULT/12826. Acesso em: 06 ago. 2019.

ASCENSIO, H.; DECAUX, E.; PELLET, A. Droit international pénal. 2. ed. Paris: Pedone. 2012.

BEASTS of no Nation. Direção: C. F. Fukunga. EUA: Netflix, 2015. 1 filme (137 min.). 
BENVENUTO, F. M. Soupçons sur la Cour pénale internationale. Le Monde Diplomatique, Paris, p. 9, abr. 2016. Disponível em: https://www.monde-diplomatique.fr/2016/04/BENVENUTO/55185. Acesso em: 16 jan. 2021.

BERNARD, D. Un (possible) apport africain à la justice internationale pénale. Études internationales, Montréal, v. 45, n. 1, p. 51 - 66, mar. 2014. Disponível em: https://www.erudit.org/fr/revues/ei/2014-v45-n1ei01412/1025116ar.pdf. Acesso em: 07 ago. 2019.

BOUQUET, C. L'impunité est-elle le prix à payer pour la démocratie en Afrique? Le Monde, Paris, jan. 2018. Disponível em: http://abonnes.lemonde.fr/afrique/article/2018/01/16/l-impunite-est-elle-le-prix-a-payer-pour-lademocratie-en-afrique_5242432_3212.html?xtmc=hissene_habre\&xtcr=3. Acesso em: 03 ago. 2019.

BOUTROS B. G. Agenda pour la paix. [s.I : s.n], [1992]. Disponível em: http://www.operationspaix.net/DATA/ DOCUMENT/1652 v Agenda_pour_la_paix.pdf. Acesso em: 06 ago. 2019.

BRICHAMBAUT, M. P. de; DOBELLE, J. F.; COULÉE, F. Leçons de droit international public. 2. ed. Paris: Presses de Sciences Po et Dalloz, 2011.

BRODY, R. The trial of Hissène Habré: a turning point for justice in Africa? Human Rights Watch, Nova lorque, fev. 2013. Disponível em: https://www.hrw.org/news/2013/02/08/trial-hissene-habre-turning-point-justice-africa. Acesso em: 01 ago. 2019.

CHAMBRE AFRICAINE EXTRAORDINAIRE D'ASSISES. Jugement Ministère Public c. Hissène Habré, Dakar: CAE, 2016. Disponível em: http://www.chambresafricaines.org/pdf/Jugement_complet.pdf. Acesso em: 06 ago. 2019.

CIVITAS MAXIMA. Follow the liberian quest for justice. [s.d]. Disponível em: https://civitas-maxima.org/page/ 2/?s=Follow+the+liberian+quest+for+justice. Acesso em: 20 fev. 2021.

CLARK, Phil. The Gacaca Courts, Post-Genocide Justice and reconciliation in Rwanda: Justice without Lawyers. Cambridge: Cambridge University Press, 2010.

COMITÉ DES NATIONS UNIES CONTRE LA TORTURE. Communication $\mathbf{n}^{\circ} \mathbf{1 8 1 / 2 0 0 1}$, Affaire Souleymane Guengueng et autres c. Sénégal, 18 mai. 2006. Disponível em: https://www.google.com/search?client=safari\&rls $=e n \& q=$ Décision $+d u+C o m i t e ́+$ contre+la+Torture+en+vertu+de+| $\% 27$ article+22+de+la+Convention. + Senegal: $+C$ omité+des+Nations+Unies+Contre+la+Torture\&ie=UTF-8\&oe=UTF-8. Acesso em: 20 fev. 2021.

CONDÉ, A. Les crises africaines seront de plus en plus résolues par les Africains. Le Monde, Paris, 30 jan. 2018. Disponível em: http://abonnes.lemonde.fr/afrique/article/2018/01/30/alpha-conde-les-crises-africainesseront-de-plus-en-plus-resolues-par-les-africains_5249360_3212.html?xtmc=hissene_habre\&xtcr=2. Acesso em: 16 jan. 2021.

COUR INTERNATIONALE DE JUSTICE (CIJ). Questions concernant l'obligation de poursuivre ou d'extrader (Bélgica c. Senegal). Arrêts, 20 jul. 2012. Disponível em: http://www.icj-cij.org/files/caserelated/144/144-20120720-JUD-01-00-FR.pdf. Acesso em: 06 ago. 2019.

COUR DE JUSTICE DE LA CEDEAO. Hissein Habré c. République du Sénégal, julgamento ${ }^{\circ}$ ECW/CCJ/ JUD/06/10, 18 nov. 2010. Disponível em: https://ihrda.uwazi.io/pt/document/2dmrkgf6x8hhrhlk0fpvrysyvi?pa ge=1. Acesso em: 20 fev. 2021.

DIAMANTE de sangue. Direção: E. Zwick. Roteiro: C. Leavitt. EUA: The Bedford Falls, 2006, DVD (134 min). EARLY, G. Afrocentrism. Cultural and political movement. Encyclopaedia Britannica. (s.d.). Disponível em: https://www.britannica.com/topic/Afrocentrism. Acesso em: 06 mar. 2018.

GWET, Y. Débat sur la CPI : C'est aux Africains de juger leurs monstres. Le Monde, Paris, 3 fev. 2016. Disponível em: https://abonnes.lemonde.fr/afrique/article/2016/02/03/c-est-aux-africains-de-juger-leursmonstres_4858700_3212.html. Acesso em: 06 ago. 2019. 
GWET, Y. L'idéal panafricain doit s'affranchir de la vision émotionnelle de l'Union Africaine. Pigeon Vert Presse, 28 jul. 2016. Disponível em: http://pigeonvertpresse.over-blog.com/2016/07/l-ideal-panafricain-doit-s-affranchirde-la-vision-emotionnelle-de-l-union-africaine-par-yann-gwet-chroniqueur-le-monde-afrique.html. Acesso em: 01 ago. 2019.

HABA, M. B. L'offensive de l'Union africaine contre la Cour pénale internationale : la remise en cause de la lutte contre l'impunité. In: UNIVERSITÉ LAVAL. Faculté de Droit. Clinique de droit international pénal et humanitaire. Canadá, 09 dez. 2013. Disponível em: https://www.cdiph.ulaval.ca/en/blogue/loffensive-de-lunionafricaine-contre-la-cour-penale-internationale-la-remise-en-cause-de-la. Acesso em: 06 ago. 2019.

HALE, Kip. What an investigation Into U.S. War Crimes in Afghanistan Would Mean. Foreign Affairs, 16 nov. 2017. Disponível em: https://www.foreignaffairs.com/articles/afghanistan/2017-11-16/why-us-can-no-longerignore-icc. Acesso em: 20 fev. 2021.

HOTEL Ruanda. Direção: T. George. Roteiro: T. George e K. Pearson. Reino Unido: África do Sul: Itália: Lions Gate Entertainment, 2004, DVD (121 min.).

HUMAN RIGHTS WATCH. Plainte contre le Sénégal devant le Comité des NU contre la Torture. Human Rights Watch, 18 abr. 2001. Disponível em: https://www.hrw.org/legacy/french/thekmes/habre-cat.html. Acesso em: 06 ago. 2019.

HUMAN RIGHTS WATCH. Reed Brody: counsel and spokesperson. Human Rights Watch, [s. d.]. Disponível em: https://www.hrw.org/about/people/reed-brody. Acesso em: 20 fev. 2021.

INTERNATIONAL CRISIS GROUP. Sierra Leone: time for a new military and political strategy. Londres; Bruxelas, 11 abr. 2001. Disponível em: https://www.crisisgroup.org/africa/west-africa/sierra-leone/sierra-leonetime-new-military-and-political-strategy. Acesso em: 16 jan. 2021.

KEOHANE, R. International Institutions and State Power: essays in International Relations Theory. Boulder: Westview Press, 1989.

KEOHANE, R.; NYE, J. Power and interdependence. 4. ed. New York: Longman, 2011.

KEOHANE, R.; NYE, J. Transnational Relations and World Politics. Cambridge: Harvard University Press, 1971.

KODJO-GRANDVAUX, S. Achille Mbembe : L'Afrique, laboratoire vivant où s'esquissent les figures du monde à venir. Le Monde, Paris, 13 ago. 2019. Disponível em: https://www.lemonde.fr/festival/article/2019/08/13/achillembembe-l-afrique-laboratoire-vivant-ou-s-esquissent-les-figures-du-monde-a-venir_5498991_4415198.html. Acesso em: 19 jan. 2021.

KOUHON, P. $30^{\circ}$ sommet UA-Moussa Faki Mahamat. Afrikipress, [Abidjã], 22 jan. 2018. Disponível em: http:// www.afrikipresse.fr/afrique/32e-sommet-ua-moussa-faki-mahamat-l-afrique-n-est-rien-du-tout-sans. Acesso em: 01 ago. 2019.

LE COMBAT des juges. Direção: Y. Billy. França: Bélgica: Zaradoc films, 2000, DVD (52 min).

LEPIDI, P. Rwanda : le TPIR est fermé mais des génocidaires vivent toujours en liberté. Le Monde, Paris, 17 dez. 2015. Disponível em: https://abonnes.lemonde.fr/afrique/article/2015/12/17/rwanda-le-tpir-est-ferme-maisdes-genocidaires-vivent-toujours-en-liberte_4833970_3212.html?xtmc=cpcr\&xtcr=6. Acesso em: 06 ago. 2019.

MBEMBE, A. Crítica da razão negra. Tradução de M. Lança. Lisboa: Antigona, 2014.

MIRANDA, J. Curso de direito internacional público. $5^{\circ}$ ed., Cascais: Princípia, 2012.

NGAMENI, H. B. La diffusion du droit international pénal dans les ordres juridiques africains. Paris: L'Harmattan, 2017. 
NGUEFEU, A. Les chambres africaines extraordinaires pour la répression des crimes internationaux. In: SOCIÉTÉ AFRICAINE POUR LE DROIT INTERNATIONAL. L’Afrique et le droit international pénal. Paris: Pedone, 2015, p. 129-168.

OLIVIER, M. Le Tribunal pénal international pour le Rwanda ferme ses portes ce 31 décembre, quel bilan ? Jeune Afrique, Paris, 31 dez. 15. Disponível em: http://www.jeuneafrique.com/290697/societe/tribunal-penalinternational-rwanda-ferme-portes-31-decembre-bilan/. Acesso em: 13 dez. 2018.

\section{ORGANISATION DES NATIONS UNIES. Accord entre I'Organisation des Nations Unies et le}

Gouvernement sierra-léonais et statut du Tribunal spécial pour la Sierra Leone. Freetown, 16 jan. 2002. Disponível em: https://ihl-databases.icrc.org/applic/ihl/dih.nsf/0/1adf75435d6055ebc1256c21003d544c. Acesso em: 20 fev. 2021.

PERRIELLO, T.; WIERDA, M. Étude de cas de tribunaux hybrides : le Tribunal spécial pour la Sierra Leone sur la sellette. Centre International pour la justice traditionnelle, [Nova lorque], 05 mar. 2006, p. 1 - 48. Disponível em: https://www.ictj.org/sites/default/files/ICTJ-SierraLeone-Tribunaux-Hybrides-2006-French.pdf. Acesso em: 06 ago. 2019.

PETITE, S. N'oublions pas que $98 \%$ des auteurs de crimes de masse échappent à toute poursuite. Le Monde, Paris, 22 jun. 2015. Disponível em: https://www.lemonde.fr/afrique/article/2015/06/22/n-oublions-pas-que-98des-auteurs-de-crimes-de-masse-echappent-a-toute-poursuite_4659293_3212.html. Acesso em: 20 fev. 2021.

ROBERT, A. C. Justice internationale, politique et droit. Le Monde Diplomatique, Paris, mai. 2003. Disponível em: https://www.monde-diplomatique.fr/2003/05/ROBERT/10176. Acesso em: 06 ago. 2019.

ROBICHEZ, J. A Justiça Penal Internacional e a África: análise crítica do "afrocentrismo" do Tribunal Penal Internacional. Cientefico, Fortaleza, v. 18, n. 38, p. 147-193, 2018. Disponível em: https://revistacientefico. adtalembrasil.com.br/cientefico/article/view/626. Acesso em: 15 jan. 2021.

SAWADOGO, R. O. Les Chambres africaines extraordinaires au sein des tribunaux sénégalais : quoi de si extraordinaire ? Études internationales, Montreal, v. 45, n. 1, p. 105-127, 2014. Disponível em: https://www. erudit.org/fr/revues/ei/2014-v45-n1-ei01412/1025119ar/. Acesso em: 20 fev. 2021.

SCELLE, G. Précis du droit des gens : principes et systématique. Paris: Sirey, 1993.

SHAKE hands with the devil. Direção: R. Spottiswoode. Canadá: Regent Releasing, 2007, DVD (113 min.). SOMA, Abdoulaye. L'africanisation du droit international pénal. In: SOCIÉTÉ AFRICAINE POUR LE DROIT INTERNATIONAL. L’Afrique et le droit international pénal. Paris: Pedone, 2015. p. 8 - 36.

SOMETIMES in april. Direção e roteiro: R. Peck. EUA: HBO, 2005. 1 filme (141 min.).

SPECIAL COURT FOR SIERRA LEONE, Appeals Chamber, Prosecutor v. Norman, "Decision on Preliminary Motion Based on Lack of Jurisdiction (Child Recruitment)", 31 maio 2004a.

SPECIAL COURT FOR SIERRA LEONE, Appeals Chamber, Prosecutor v. Morris Kallon \& Brima Bazzy Kamara, "Decision on challenge to jurisdiction: Lomé accord amnesty", caso n. ${ }^{\circ}$ SCSL-2004-15-1R72 (E), §84, 13 mar. 2004b,

TILOUINE, J. L'Afrique veut-elle vraiment juger ses dictateurs, ou le procès d'Habré restera-t-il une exception ? Le Monde, Paris, 20 jul. 2015. Disponível em: http://abonnes.lemonde.fr/afrique/article/2015/07/20/l-afriqueveut-elle-vraiment-juger-ses-dictateurs-ou-le-proces-hissene-habre-restera-t-il-une-exception_4690745_3212. html?xtmc=ben_kioko\&xtcr=1. Acesso em: 06 ago. 2019.

TILOUINE, J.; KADIRI, G. Alpha Condé : Les crises africaines seront de plus en plus résolues par les Africains. Le Monde, Paris, 30 jan. 2018. Disponível em: http://abonnes.lemonde.fr/afrique/article/2018/01/30/ alpha-conde-les-crises-africaines-seront-de-plus-en-plus-resolues-par-les-africains_5249360_3212. html?xtmc=hissene_habre\&xtcr=2. Acesso em: 06 ago. 2019. 
TRINDADE, A. A. C. Os tribunais internacionais e a realização da justiça. Rio de Janeiro: Renovar, 2015.

UNION AFRICAINE. Décision sur le procès Hissein Habré et l'Union africaine. Doc. ASSEMBLYIAU/3 (VII), 02 jul. 2006. Disponível em: https://au.int/sites/default/files/decisions/9555-assembly_fr_01_july_03_july_2006_ auc_seventh_ordinary_session_decisions_declarations_0.pdf. Acesso em: 20 fev. 2021.

UNICEF. Peace process falters for child soldiers of Sierra Leone. Freetown, 22 jul. 2003. Disponível em: https://www.unicef.org/media/media_12200.html. Acesso em: 06 ago. 2019.

WUILBERCQ, E. L'Afrique veut-elle vraiment en finir avec la Cour pénale internationale? Le Monde, Paris, 03 fev. 2017. Disponível em: https://abonnes.lemonde.fr/afrique/article/2017/02/03/l-afrique-veut-elle-vraiment-enfinir-avec-la-cour-penale-internationale_5074120_3212.html?xtmc=oxfam_union_africaine\&xtcr=5. Acesso em: 01 ago. 2019.

ZOLO, Danilo. La justice des vainqueurs: De Nuremberg à Bagdad. Arles: Ed. Jacqueline Chambon, 2009.

Recebido em: 21/01/2020

Aprovado em: 02/03/2020 